\title{
HOW CAN SOLIDARITY IN A COMMUNITY IMPROVE THE QUALITY OF LIFE?
} Elvira KUHN, professor at the Institute/department of business informatics, Faculty of economy, University of applied sciences Trier,
Schneidershof, 54293 Trier, Germany, e.kuhn@ @ochschule-trier.de

\begin{abstract}
Our thesis states that the social capital can increase through establishing a union of solidarity. By achieving this, we will not only create new places of employment, support, acceptance, friends and social relationships, but also gain additional knowledge and build networks. We show that the quality of life will be influenced by solidarity by discussing different projects. At first, we discuss concepts like acceptance, network, knowledge in the context of solidarity, as well as quality of life. After establishing the definitions, we allocate to these terms different criteria, which will be the foundation of examining the success of the projects. Hereby the items of investigation for each project are the objectives, the proposed solutions and alternative routes for achieving the goals, as well as the achieved level of solidarity. Substantial influencing values, obstructive or conducive, are carved out and named, leading to applicable commendations. At last, we show the possibilities to augment the solidarity of rural areas by using information systems, as well as consider the limitations. In conclusion, we discuss the effects of staying together on the quality of life. In the analysis of the exemplary projects, the diversity of approaches is surprising: it spans from the establishment of a special office in the administration, to the communal plantation of fruits and vegetables for their own needs, to the sharing of knowledge or the locating of new partners for cooperation through networking. Eventually, essential determining factors for the success of solidarity in communities are the establishment of a common culture, shared interests and a well-functioning communication.
\end{abstract}

Keywords: networking, permanent learning, political and IT-technical information influences, solidarity union.

\section{INTRODUCTION}

The scientific problem, as it is relevant for rural development, is the following: Rural areas in Germany are affected by the exodus of young people, unemployment, ageing of the population. Old ramshackle houses and streets are part of the scenery. Small villages, that are often far apart from each other, rarely participate in infrastructural developments, especially IT. Additionally, information technology is prevalently in low regard of the elderly population. The main questions of the indicated object are the following: What are the challenges to achieve the goal of improving the quality of life in rural areas? What kind of processes need to be initiated, which roles are necessary and what part can IT play in this? Therefore, our research aim can be formulated: It is to present sustainable solutions on the basis of appropriate organizational structures and applicable commendations to improve the quality of life. This means, we have to find out what kind of organizations are necessary to improve the social responsibility. The organizations may be companies or political institutions. The relationship between political and economic context are part of our concern too. Our research tasks are, at first, to analyze the problems which deteriorate solidarity, at second, to describe quality of life and at third, the connection between solidarity and quality of life. After these, we can look at activities to enrich solidarity. Consequently, we are describing the influencing values on possible solutions on the basis of the exhibited problems in this article and evaluating these solutions. To make sure that the solutions persist in a sustainable manner, the necessary skills of the participants will be discussed. The subject of the remarks are existing projects and their approaches to handle the depicted problems. These possibilities shall be examined in regards of their feasibility to be implemented in rural areas and of their sustainability. At the end, we will show the chain of functions graphically for all of our different solutions, in order to make the positive and negative effects on the initial problem field visibly evident. This will lead to concrete commendations for action.

\section{RESEARCH METHODS}

Our theoretical material consists of the clarification of terms, the deduction of criteria to assess the level of gratification with the underlying intention of each term, and the application of these criteria in the assessment of ongoing projects. Hereby, we examine the approaches in regards of the usability in rural areas, employing analytical

Copyright (C) 2017 The Authors. Published by Aleksandras Stulginskis University. This is an open-access article distributed under the terms of the Creative Commons Attribution License (CC-BY 4.0), which permits unrestricted use, distribution, and reproduction in any medium, provided the original author and source are credited. 
methods from the field of Software Engineering. This will secure a common understanding of the terms when being used in this article. The constriction to the perspective on rural development provides the possibility to focus on this subject despite of its complexity. The analyzed projects are well known to the author, as she participates in them herself. They only serve as examples for possible approaches and are in no way to be understood as an exhaustive template of all possible solutions. The employed representation method to amend the legibility is the chain of functions (Forrester, 1972).

\section{RESEARCH RESULTS}

We present our research results in the separate phases as described above. Since rural areas are to be revived (Schneider, 2016), this means that numerous people will move in, who will need to get to know each other and build a mutual trust among themselves. To strengthen togetherness, one must strengthen solidarity. The term solidarity is used in a general fashion, the willingness of each citizen to stand up for the "whole, for the total sum". It is a "basic principle of human cohabitation" and mediates "a feeling of belonging together to individuals and groups". This reciprocal help and the advocacy for one another can be found in Germany in varying organizational types of cooperation, such as associations, book and debate clubs, political regulars' tables and many more. The Duden (solidarity definition...2017) shows us in addition that solidarity signifies a feeling of team spirit and a mutual support based on reciprocal intercession. As can be found in (about the future...2011) Europe can only "succeed in managing the challenges of the $21^{\text {st }}$ century through the development of cooperative strength in order to achieve the necessary creative power". Supporting these types of cooperation must therefore be of great consideration when planning the rural development activities. When taking the next step and examining the quality of life as a whole, we recognize "Quality of life" as the general well-being of individuals and societies, outlining negative and positive features of life. It observes life satisfaction, including everything from physical health, family, education, employment, wealth, religious beliefs, finance and the environment. The (Better life index...2017) lists the multiple factors for each European country in the order of importance for the respective population. The following factors are named: Housing, meaning the housing conditions and spending; Income, the household income and financial wealth; Jobs, signifying earnings, job security and unemployment; Community, the quality of your social support network; Education, for your level education and what you get out for it, quality of your Environment; Civic Engagement, meaning your involvement in democracy; Health, indicating how healthy you are; Life Satisfaction, standing for your overall happiness; Safety, the murder and assault rates of a country and Work-Life Balance. In order to identify actions that will improve these factors, we will firstly take a closer look at additional terms that are related to these factors, starting with the term acceptance. Oliver Quiring (methodical aspects....2006) describes acceptance as determining the motives behind embracing or rejecting an already introduced innovation. He lists the following criteria to assert the level of acceptance: Relative Advantage: The degree to which an innovation is seen as an improvement in comparison to its predecessors. So, the advantages have to be clearly visible. Compatibility: The degree as to which an innovation is consistent with existing values, experiences and needs. Existing needs must be taken into account and, ideally, satisfied. Complexity: How hard is it to understand and use the innovation? The term Usability is here more common in IT. Trialability: The possibility to test early stages or different aspects of the innovation in a small, controlled environment. This rating should be conducted by consumers, not experts. Observability: Can the benefit of the innovation be observed easily? This criterion is crucial for the willingness to use and adopt the innovation. In the research field of rural development, the acceptance of novelties is essential, especially since they should be sustainable, as the term expression development suggests. Therefore, these criteria should be used when assessing the success of our projects, since rural development always signifies innovation and change. Closely related to the term acceptance is the term happiness, which influences economic growth, according to Kleist \& Maetrz (Change Management...2003). It can be characterised by the following factors: familial ties, financial situation, jobs/work, social environment, health, personal freedom and life philosophy. These factors of happiness determine the content of human beings and thus also the will to live and work in the countryside, provide these needs can be fulfilled there. Only after sufficient people live in rural areas, social relationships for everyone can be established with certitude. These social ties refine the aforementioned factor „familial ties“, and is expressed in the private life through the existence of circles of friends and adventurousness, while in the work environment the code of conduct in dealing with colleagues is the dominant aspect. This last point can be extended by building networks. Here, the factor trust gains significance, as well as the willingness to share knowledge. Additional knowledge disbands boredom in the private area. At work, continuous learning and expanding one's knowledge is inevitable because of the fast changes and innovations in the environment of the enterprise. An additional factor is the support through eLearning, since local training would be too expensive, too difficult to plan ad hoc and too cumbersome in rural areas. Using E-Learning also means not tob e afraid of employing IT. As this is often the case, training sessions need to be offered commonly (Kuhn E.2013, KuGrRi2014, Kuhn E. 2016). Obviously, the necessary infrastructure has to be available (Förderung der Dorferneuerung...2016, Dorfumbau....2014).

After acknowledging the relevant factors for rural development, we will now establish the connection between solidarity and quality of life. The following table is to be read in a way that the influencing factors on solidarity can be seen in the columns, the factors regarding quality of life in the rows. 0 signifies no, 1 little and 2 strong influence. The assessment is based on personal experience, non-representative surveys and debates on the subject of quality of life on conferences. 
Table 1. Connection between Solidarity and quality of life

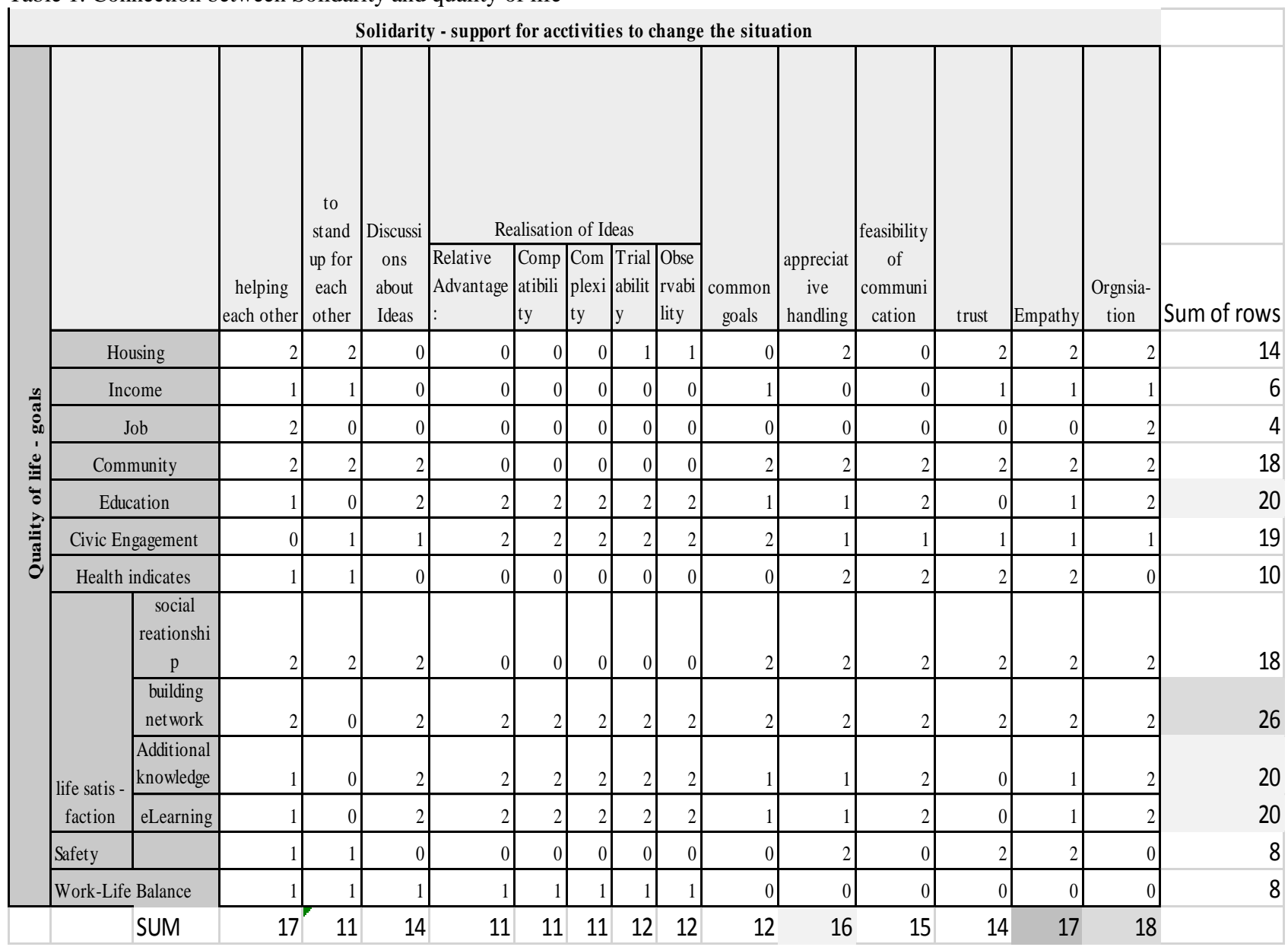

As can be seen in the table, the factors of solidarity influence the quality of life to different extend. The factor solidarity affects most factors of QoL (- it has the highest rate in the columns -) and needs to be regarded with the highest priority. The QoL-factor Building Network is being influenced by the most factors of solidarity ( - it has the highest rate in the rows -) and is also the hardest to achieve. Before we analyse different real projects in relation to the listed criteria, we represent the projects. By examining a moon-shot project in Germany in Trier called SOLAWI, we are able to see the possibilities of encouraging citizens to work conjointly on agricultural land to produce fruits and vegetables for their own needs. The focus is on common work, on common effort and on common results. Another project in rural areas is the initiative of consolidating small and medium sized enterprises, by offe ring a breakfast each week on a fixed date and time with the focus on networking. The newcomers, who have to be invited, only have one minute to present themselves. Afterwards, cards can be exchanged. The third project is the threemonth-interval meeting offered by equal opportunity commissioners in plural communes for female entrepreneurs. Here the women have the opportunity to adopt new knowledge and to compare notes with experts or other entrepreneurs about actual problems or new situations. In addition, we will discuss the latest project to establish new work places in the EIFEL by forming a special position for a single person to assess and inform people about recent possibilities.

Applying the criteria to the projects results in the following situation in the Table 2. In this figure, $\mathrm{Y}$ is taken into account, $\mathrm{N}$ is ignored, 0 is random, but is not explicitly supported in the concept. As we can see, all of our projects take into account the factors Discussions about Ideas, common goals, appreciative handling, feasibility of communication and organisation out of the area solidarity and community, education, social relationship, building network and additional knowledge out of the area quality of life. 
Table 2. Actual Situation in real projects

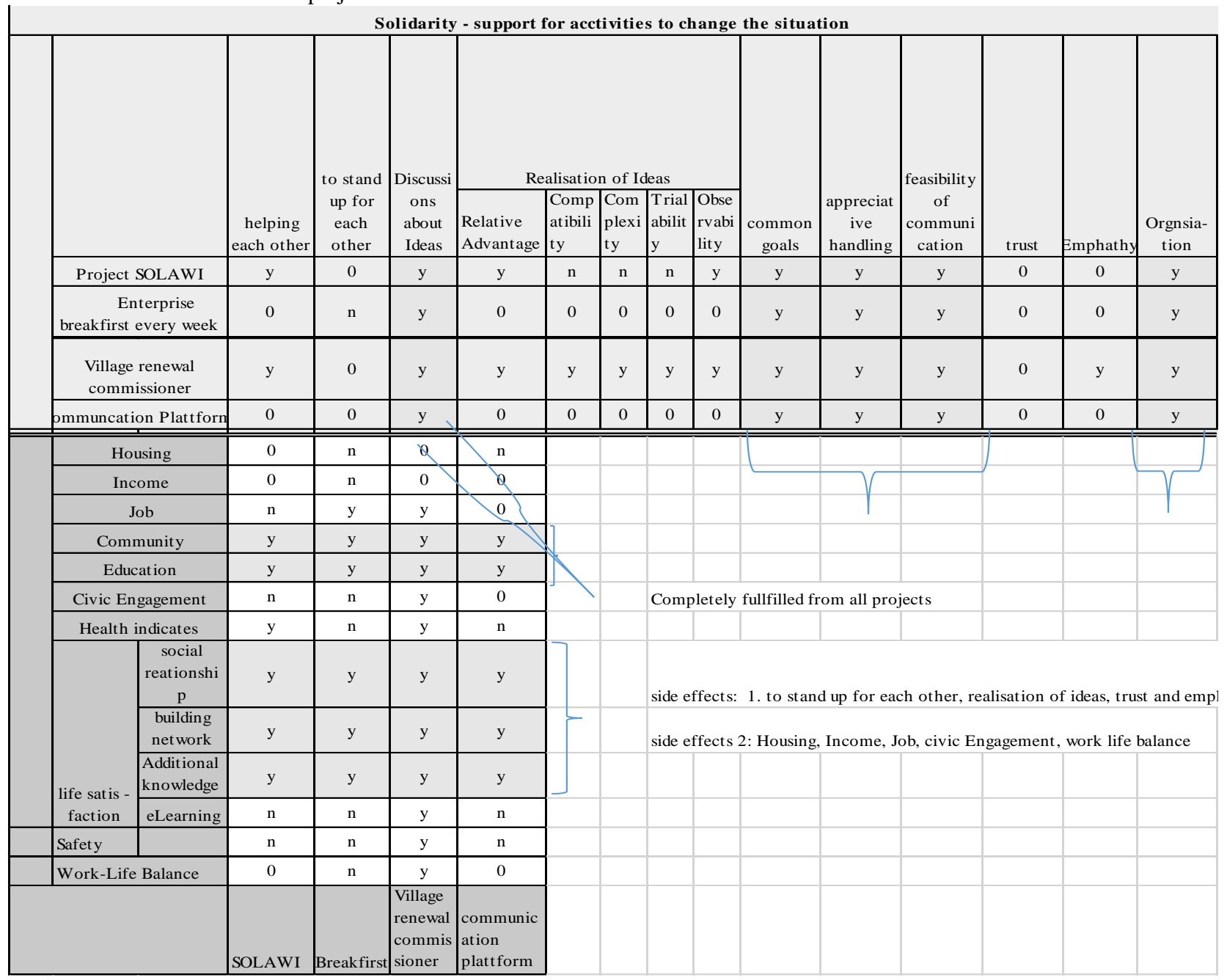

Let's take a closer look at these side effects (0):
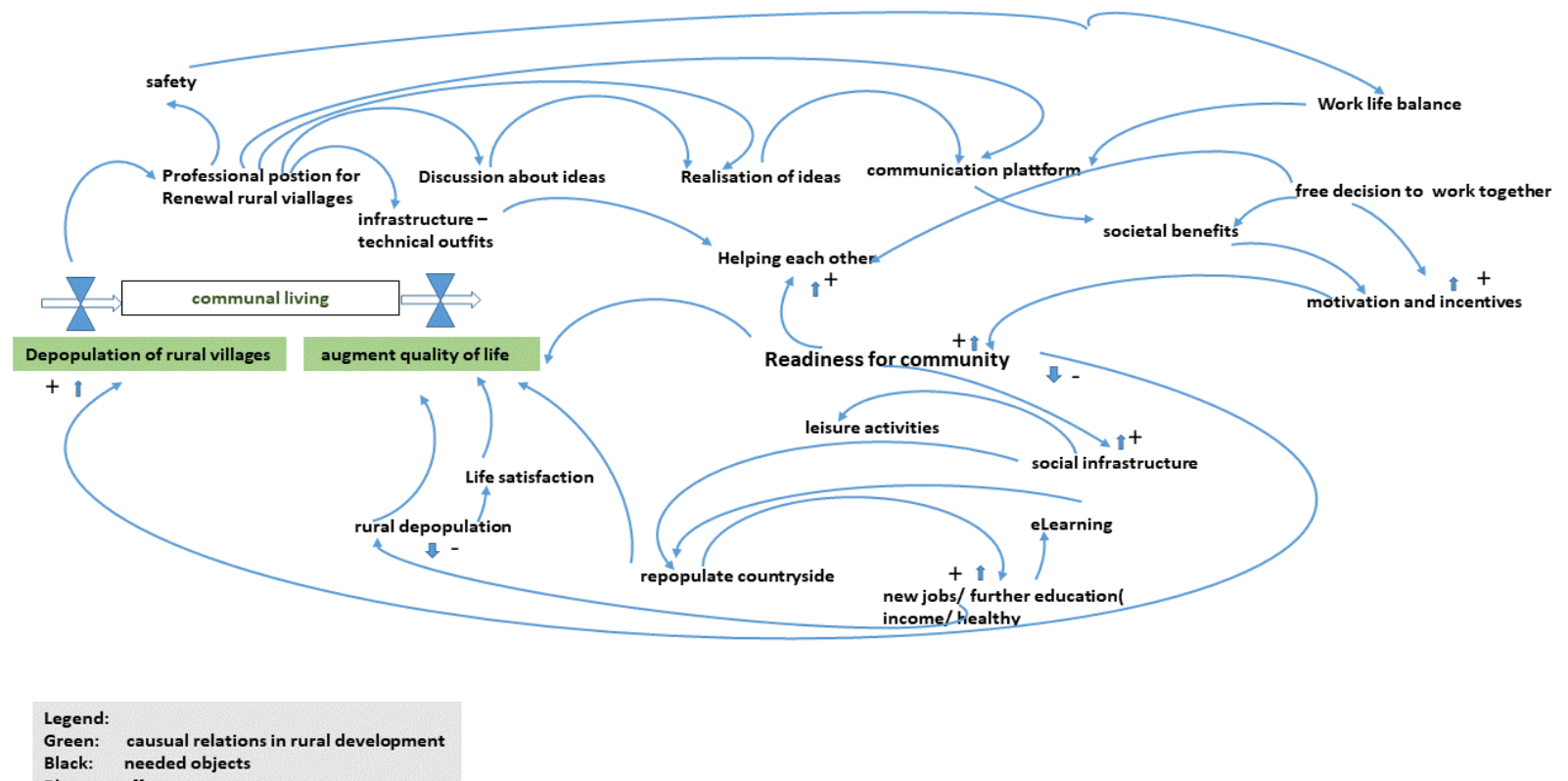

Figure 1. Interactions of side effects - feedback model based on the method of J. W. Forrester (1972) 
These side effects may be conducive or hindering the named objects. In Figure 1, we marked the influence to increase the above objects with + , to decrease with - on the end of the arrowhead. We therefore give the following recommendations for action, shown in Table 3.

Table 3. Processes and roles, which are necessary to augment good side effects

\begin{tabular}{|c|c|c|c|c|c|c|c|c|c|c|}
\hline good side effects & $\begin{array}{c}\text { helping } \\
\text { each other }\end{array}$ & $\begin{array}{l}\text { to stand } \\
\text { up for } \\
\text { each } \\
\text { other }\end{array}$ & $\begin{array}{c}\text { Realisation } \\
\text { of Ideas }\end{array}$ & trust & Empathy & Housing & Income & Job & $\begin{array}{c}\text { Civic } \\
\text { Engagem } \\
\text { ent }\end{array}$ & $\begin{array}{c}\text { Work-Life } \\
\text { Balance }\end{array}$ \\
\hline \multirow[t]{13}{*}{ Process/ Role } & $\begin{array}{l}\text { event- } \\
\text { manage- } \\
\text { ment } 1\end{array}$ & $\begin{array}{l}\text { self } \\
\text { motivati } \\
\text { on/ } 0\end{array}$ & \begin{tabular}{|l} 
IT- \\
plattforms/ \\
1
\end{tabular} & $\begin{array}{l}\text { self } \\
\text { motivati } \\
\text { on/ } 0\end{array}$ & $\begin{array}{l}\text { self } \\
\text { motivati } \\
\text { on/ } 0\end{array}$ & $\begin{array}{l}\text { solidarity } \\
\text { union/1 }\end{array}$ & $\begin{array}{l}\text { plattfor } \\
\text { m (IT)/1 }\end{array}$ & $\begin{array}{l}\text { plattfor } \\
\text { m (IT)/1 }\end{array}$ & $\begin{array}{l}\text { plattfor } \\
\text { m (IT)/5 }\end{array}$ & networking 6 \\
\hline & $\begin{array}{l}\text { solidarity } \\
\text { union/1 }\end{array}$ & $\begin{array}{l}\text { church/ } \\
3\end{array}$ & $\begin{array}{l}\text { meetings } / 1 \mathrm{o} \\
\mathrm{r} 2\end{array}$ & church $/ 3$ & & $\begin{array}{l}\text { plattform } \\
\text { (IT)/1 }\end{array}$ & $\begin{array}{l}\text { net worki } \\
\text { ng } 1 \text { or2 }\end{array}$ & $\begin{array}{l}\text { ing } 1 \\
\text { or2 }\end{array}$ & $\begin{array}{l}\text { networki } \\
\text { ng } 5\end{array}$ & $\begin{array}{l}\text { plattform } \\
\text { (IT) } / 6\end{array}$ \\
\hline & $\begin{array}{l}\text { plattform } \\
\text { (IT)/1 }\end{array}$ & $\begin{array}{l}\text { educatio } \\
\mathrm{n} / 4\end{array}$ & $\begin{array}{l}\text { networking } \\
1 \text { or } 2\end{array}$ & & & $\begin{array}{l}\text { networki } \\
\text { ng } 1 \text { or2 }\end{array}$ & & & $\begin{array}{l}\text { meetings/ } \\
5\end{array}$ & \multirow{2}{*}{$\begin{array}{l}\text { support for } \\
\text { children/ } \\
\text { elderly people/ } \\
6\end{array}$} \\
\hline & \begin{tabular}{|l} 
meetings/ \\
1or2
\end{tabular} & & & & & & & & $\begin{array}{l}\text { event- } \\
\text { manage- } \\
\text { ment } 5\end{array}$ & \\
\hline & $\begin{array}{l}\text { net- } \\
\text { working1 } \\
\text { or2 }\end{array}$ & & & & & & & & & \\
\hline & & & & & & & & & & \\
\hline & \multicolumn{3}{|c|}{1 Village renewal commissioner } & & & & & & & \\
\hline & 2 citizens & & & & & & & & & \\
\hline & 0 no role & & & & & & & & & \\
\hline & 3 priest & & & & & & & & & \\
\hline & 4 teacher & & & & & & & & & \\
\hline & 5 politicial & & & & & & & & & \\
\hline & 6 entreprer & neur & & & & & & & & \\
\hline
\end{tabular}

In Table 3, there are often the same processes but other responsibilities needed. To minimize bad side effects, the village renewal commissioner must ensure that new founders settle down and the sense of community is strengthened.

\section{CONCLUSIONS}

To round off the result of improving the quality of life in rural areas, we also compile the recommendations for action based on the factors analysed. As we have seen in Table 1 the most important factor for success to have a good organisation, following up empathy and appreciative handling. To support a good organisation for the needed innovation process rural development we recommend an antifragile organisation with the IT support. The project management needs to do by Scrum. The second factor is hard to handle. Perhaps with the help of psychoanalysis, we can increase the value of this factor. The third factor belongs to the soft skills and addresses the education by yourself or by an educator.

We have shown that each has to move towards each other. We need a culture of solidarity to be successful in rural development and to be healthy and active for our whole life. It is clear that education and training work needs to be done professionally as soon as possible to get people living in rural areas to use IT.

\section{ACKNOWLEDGEMENTS}

Round about 120 students of the University of Applied Sciences Trier have worked on some of these projects between 2015-2017 and they have created workflows for the needed activities to meet the targets.

\section{REFERENCES}

1. Deutsche Landeskulturgesellschaft DLKG Dorfumbau: Dörfer entstehen im Kopf! Wie können die Veränderungsprozesse mit den Menschen gestaltet werden? 2014. [Village restructuring: villages are created in the head! How can change processes be shaped with people?] [In German]

2. Duden Suchen. [Solidarity Definition]. Available at: https://www.duden.de/suchen/dudenonline/Solidarit\%C3\%A4t (Acessed on 11/11/2017) [In German] 
3. European Union: Solidarity and Forces: About the future of European Union, 19. Okt. 2011 Available at: https://www.boell.de/de/demokratie/institutionen-governance-solidaritaet-und-staerke-zur-zukunft-der-europaeischen-union13079.html

4. Förderung der Dorferneuerung

[Promotion

of village renewal]. https://mdi.rlp.de/fileadmin/isim/Unsere_Themen/Staedte_und_Gemeinden/Dokumente/Dorferneuerung/Foerderung_der_Dorf erneuerung_VV-Dorf_pdf (Accessed on 05/06/2016) [In German]

5. Kleist, S., Maetz, H., 2003. Widerstände im Change-management, in G. Schewe, Change-Management - facetten und Instrumente, Kovac Hamburg, pp. 53-68. [Resistance in change management - facets and instruments] [In German]

6. Kuhn, E. 2013. Cloud Computing and the consequences - the new territory for public organization. Tagungsband Management Conference "Effective Organization", 11.Juni 2013, Polen, Siedlce.

7. Kuhn, E., Grumbach, I., Richert, V., Können spezielle IT Konzepte für die alternde Bevölkerung zur Steigerung der Lebensqualität beitragen? Vorstellung eines Konzepts für 55+, in News\&Media, Berlin 2014, AKWI Prozesse, Technologie, Anwendungen, Systeme und Management, Tagungsband $2014 . \quad$ Published also in http://www.akwi.de/AKWI_TAGUNG_2014.pdf [Can specific IT concepts help the aging population increase their quality of life? Presentation of a concept for 55+]. [In German]

8. Kuhn E., Hochschule, T. 2016. Was muss eHealth leisten, um allengerechtes Woh-nen auf dem Lande zu ermöglichen? Vortrag in Berlin, DGGÖ-Workshop, EHealth-Ökonomie, 16.03.2016, [What does eHealth have to do to enable all-round living in the countryside?] [In German]

9. Meadows, D. Rückkopplungsmodell in Anlehnung an die Methode von J. W. Forrester, in Dennis Meadows, Die Grenzen des Wachstums, Bericht des Club of Rome zur Lage der Menschheit, dt. Verlag - Anstalt Stuttgart, 1972. [ Feedback model based on the method..... The Limits of Growth, Report of the Club of Rome on the Situation of Humanity]. [In German]

10. OECD Better Life Index http://www.oecdbetterlifeindex.org/de/ (Accessed on 11/11/2017)

11. Quiring, O. 2006. Methodische Aspekte der Akzeptanzforschung bei interaktiven Medientechnologien, Elektronische Publikationen der Universität München. Kommunikations und Medienforschung. Münchener Beiträge zur Kommunikationswissenschaft, No. 6. URL: http://epub.ub.uni- muenchen.de/archive/00001348/(accessed on 17/05/2016) [Methodological Aspects of Acceptance Research in Interactive Media Technologies, Electronic Publications of the University of Munich. Communication and media research.Münchener contributions to communication science]. [In German]

12. Schneider, S. L.2016. Wie kann die Attraktivität zum allengerechten Wohnen in einer ländlichen Gegend für Studierende und junge Arbeitnehmer erhöht werden? Konzeption zum Erhalt kultureller Vielfalt und nachhaltiger Versorgung am Beispiel der Eifel., Bachelor Thesis an der Hochschule Trier, FB Wirtschaft, Betreuerin: Prof. Dr. E. Kuhn, 2016. [How can attractiveness for fair living in a rural area be increased for students and young workers? Conception for the preservation of cultural diversity and sustainable care using the example of the Eifel.] [In German] 